\title{
Yield and quality of strawberry hybrids under subtropical conditions
}

\author{
E. Barth ${ }^{1}$, J.T.V. de Resende ${ }^{2,5}$, A.R. Zeist ${ }^{3,6}$, K.H. Mariguele ${ }^{4}$, \\ R.A. Zeist ${ }^{5}$, A. Gabriel ${ }^{5}$, C.K. Camargo ${ }^{5}$ and F. Piran ${ }^{5}$ \\ ${ }^{1}$ Empresa de Pesquisa Agropecuária e Extensão Rural, Pomerode, SC, Brasil \\ ${ }^{2}$ Universidade Estadual de Londrina, Londrina, PR, Brasil \\ ${ }^{3}$ Universidade Federal de Lavras, Lavras, MG, Brasil; \\ ${ }^{4}$ Empresa de Pesquisa Agropecuária e Extensão Rural, Itajaí, SC, Brasil \\ ${ }^{5}$ Universidade Estadual do Centro-Oeste, Guarapuava, PR, Brasil \\ ${ }^{6}$ Universidade do Oeste Paulista, Presidente Prudente, SP, Brasil \\ Corresponding author: E. Barth \\ E-mail: earth@epagri.sc.gov.br
}

Genet. Mol. Res. 18 (2): gmr18156

Received September 24, 2018

Accepted February 21, 2019

Published May 03, 2019

DOI http://dx.doi.org/10.4238/gmr18156

\begin{abstract}
Strawberry (Fragaria $x$ ananassa) stands out among small fruits as the most planted in Brazil, generating considerable income and employment. However, producers are dependent on cultivars originating from international breeding programs and imported seedlings. This entails high costs and plants poorly adapted to the edaphoclimatic conditions of Brazil. In addition, the consumer market demands superior organoleptic and nutritional qualities. We assessed the potential of 194 hybrids for production and physicochemical characteristics from a population of seedlings obtained from intraspecific crosses of the short-day cultivars Dover, Camarosa, Sweet Charlie, Oso Grande, Milsei Tudla, and Festival Florida and the day-neutral cultivar Aromas. The experimental design was an augmented block design that had as control treatments the cultivars Camarosa and Camino Real. Five production and nine physicochemical characteristics were assessed. The mean comparison was performed by the Dunnett test. Among the 14 characteristics analyzed, eight presented significance. The significant production characteristics were the number of commercial fruits, mass of commercial fruits, mass of non-commercial fruits, and the total mass
\end{abstract}


of fruits, with values of 45.03 fruits/plant, $13.17 \mathrm{~g}, 72.22 \mathrm{~g} / \mathrm{plant}$, and $720.77 \mathrm{~g} /$ plant, respectively. The physicochemical characteristics that varied significantly were soluble solids to titratable acidity ratio, pectin, ascorbic acid, and anthocyanin, which presented values of $10.23,2.06 \mathrm{~g}$ total pectin/100 g pulp, $71.12 \mathrm{mg}$ ascorbic acid/100 g pulp, and $39.51 \mathrm{mg}$ cyanidin 3-glycoside/100 g pulp, respectively. The crosses that involved Camarosa and Aromas gave a greater number of hybrids with superior positive effects when compared to the controls in terms of production and physicochemical characteristics, respectively. Among the 194 hybrids, 30 were superior to the controls and were selected to advance in the breeding program.

Key words: Strawberry; Breeding; Augmented blocks

\section{INTRODUCTION}

World strawberry (Fragaria $x$ ananassa) production was more than nine million tons in 2016, with China being the world's largest producer, followed by the United States (FAO, 2016). In Brazil, the planted area is about 3500 hectares, with an estimated production of more than 105 thousand tons per year (Antunes, 2010). The yearly demand in Brazil is about 175,000,000 seedlings. Their cultivation generates considerable employment and income, especially in family farming (Antunes and Peres, 2013).

The seedlings planted in Brazil are mainly imported from Argentina and Chile. This dependence on foreign nurseries affects production costs. This is due to importation costs and intellectual property rights agreements that require the payment of royalties. In addition, these seedlings only arrive at the end of April, hampering producers in regions where climate conditions allow planting to begin in March, which can result in better prices from earlier harvests (Antunes and Peres, 2013).

Several genotypes used in Brazilian breeding programs were introduced from the United States by the importation of seedlings and achenes. United States breeding programs began in the 19th century, while in Brazil they initiated only in the 1940s (Antunes and Peres, 2013). Initially, they prioritized production characteristics. However, selection based on only some characteristics may be a disadvantage for others, since unfavorable, negative or positive correlations may occur between them (Hancock et al., 2008).

The Brazilian public breeding programs have suffered discontinuity; between 1998 and 2014, they registered only eight cultivars (Gomes et al., 2016). The dependence on limited genetic material for the different edaphoclimatic conditions in Brazil has been a major obstacle for producers since various cultivars are not resistant to diseases, have a bland taste, and are not adapted to the different Brazilian agricultural regions (Fagherazzi et al., 2017).

The State University of Midwest of Paraná (UNICENTRO), in an interinstitutional cooperation with the Federal University of Lavras (UFLA), resumed the identification and selection of superior genotypes. Embrapa Temperate Agriculture resumed the program from 2008, after a discontinuity of almost 10 years, for the formation of a germplasm bank using local variability (Antunes and Peres, 2013). 
The selection of genotypes for Brazilian conditions that take into account production and physicochemical characteristics is of fundamental importance for crop advancement in order to offer more nutritious and tasty fruits. The reactivation and strengthening of breeding programs in Brazil can produce better adapted and productive cultivars, providing an increase in income, crop health, reduced costs of seedlings, and improved nutritional characteristics.

To this end, we assessed strawberry genotypes obtained from intraspecific crosses for production and physicochemical characteristics under Brazilian subtropical conditions.

\section{MATERIAL AND METHODS}

\section{Obtaining hybrids}

The populations of seedlings were obtained by crossing between the commercial strawberry cultivars 'Dover' $x$ 'Aromas' (DA), 'Camarosa' x 'Aromas' (CA), 'Dover' $x$ 'Sweet Charlie' (DS), 'Oso Grande' x 'Milsei Tudla' (OM), 'Festival Florida' x 'Sweet Charlie' (FS), 'Sweet Charlie' x 'Aromas' (SA), 'Milsei Tudla' x 'Aromas' (MA), 'Milsei Tudla' x 'Sweet Charlie' (MS), 'Camarosa' x 'Sweet Charlie' (CS), and 'Festival Florida' $x$ 'Aromas' (FA). The cultivar Aromas is characterized as a day-neutral cultivar and the cultivars Camarosa, Dover, Festival Florida, Oso Grande, Sweet Charlie, and Milsei Tudla are characterized as short-day cultivars (Coelho Jr, 2016; Oliveira and Antunes, 2016).

After crosses, formation, and development of fruits, achenes were removed, desiccated, scarified, and germinated in vitro, as described by Galvão et al. (2017). At 60 days after germination, when the seedlings reached four to five true and expanded leaves, they were transplanted to 72-cell polypropylene trays containing a biostabilized pine barkbased substrate.

During acclimatization, the trays were maintained in a greenhouse with nebulization and controlled temperature. For seedling development, three applications of $2 \mathrm{~mL}$ of liquid fertilizer containing 50\% of MS salts (Murashige and Skoog, 1962) per plant.

\section{Experimental area}

A total of 194 hybrids were transplanted in July 2013 in an experimental area of the Center for Research in Vegetables of the Department of Agronomy of the State University of the Midwest (UNICENTRO), located in Guarapuava, PR, Brazil $\left(25^{\circ} 38^{\prime} \mathrm{S}, 51^{\circ} 48^{\prime} \mathrm{W}\right.$, and 1100 meters altitude), belonging to the Paraná Third Planalto region. According to the Köppen classification, the regional climate is type $\mathrm{Cfb}$ (humid mesothermal subtropical), i.e. a temperate climate without a defined dry season and with a warm summer and a moderate winter (Wrege et al., 2011). The soil is classified as an Oxisol (Latossolo Bruno distroférrico típico, Brazilian Soil Classification System). Transplanting was performed in a tunnel system of $0.8 \mathrm{~m}$ height in the central part and in beds of $1.0 \mathrm{~m}$ wide and $0.25 \mathrm{~m}$ high covered with a black polyethylene film. To cover the tunnels, $120-\mu \mathrm{m}$ thickness transparent polyethylene films were used. The spacing used was $0.30 \times 0.40 \mathrm{~m}$, forming two rows.

The experimental design was an augmented block design (Federer, 1956), with the commercial cultivars Camarosa and Camino Real as control treatments. The experimental F1 hybrids from crosses were arranged in 10 blocks, each of them composed by a bed. 
These beds were fertilized with $1650 \mathrm{~kg} / \mathrm{ha}$ of single superphosphate, $250 \mathrm{~kg} / \mathrm{ha}$ of potassium chloride, and $295 \mathrm{~kg} / \mathrm{ha}$ of urea, based on the soil chemical analysis. For irrigation, a micro drip system was used according to the water requirements of the crop. Preventive sprayings with thiamethoxam and azoxystrobin + diphenoconazole were used for phytosanitary control. Harvesting began when the fruits reached the maturation stage, with $75 \%$ dark red color.

\section{Assessed agronomic characteristics}

The agronomic and physicochemical characteristics were analyzed in the laboratory. The data of the number of commercial fruits per plant (NCF), average mass of commercial fruits (AMCF) in g/plant, mass of commercial fruit (MCF) in g/plant, mass of non-commercial fruits (MNCF) in g/plant, and total mass of fruits (TMF) in g/plant were obtained from these analyses.

\section{Assessed physicochemical characteristics}

The physicochemical characteristics were obtained from samples of ripe strawberries stored during harvest in a horizontal freezer, maintained at $-2^{\circ} \mathrm{C}$. For the analyses, the strawberry samples were thawed, ground, and homogenized. Quality assessments were carried out from the homogenized pulp, which consisted of $\mathrm{pH}$, soluble solids (SS), titratable acidity (TA) soluble solids to titratable acidity ratio (Ratio), reducing sugars (RS), and pectin (PEC). In addition, assessments of bioactive compounds were also carried out, which consisted of ascorbic acid (AA), phenolic compounds (PC), and anthocyanins (ANT).

\section{Statistical analysis}

The data were analyzed with the statistical program Genes (Cruz, 2013), with which the analysis of variance and the comparison between means of the hybrids and controls were performed by the Dunnett test $(\mathrm{P} \leq 0.05$ and $\leq 0.01)$.

\section{RESULTS}

Among the 14 characteristics that we analyzed, eight presented significance in the comparisons of averages of the hybrids. The significant production characteristics were NCF, MCF, AMCF, and TMF, with values of 45.03 fruits/plant, $13.17 \mathrm{~g}, 72.22 \mathrm{~g} / \mathrm{plant}$, and 720.77 $\mathrm{g} / \mathrm{plant}$, respectively. The physicochemical characteristics that presented significance were Ratio, PEC, AA, and ANT, with values of 10.23, $2.06 \mathrm{~g}$ total pectin/100 g pulp, $71.12 \mathrm{mg}$ ascorbic acid/100 g pulp, $39.51 \mathrm{mg}$ cyanidin 3-glycoside/100 g pulp. In comparison Camargo et al. (2018), in an evaluation of 15 hybrids of commercial cultivars, obtained averages of 9.52, $147.8 \mathrm{mg}$ ascorbic acid/100 g pulp, $65.5 \mathrm{mg}$ cyanidin 3-glycoside/100 g pulp for Ratio, AA and ANT, respectively. The ratio value obtained by these authors was lower than the value obtained in our study, but the vitamin $\mathrm{C}$ and anthocyanin characteristics were superior.

Genetic variability is evident when higher standard deviation values are observed between hybrids when compared to the controls (Table 1). Evaluation of hybrids may demonstrate diversity, considering that the genotypes will express a combination of parental 
genes (Capocasa et al., 2008). In addition, when the ploidization phenomenon occurs spontaneously in nature through the union of non-reduced gametes (Schifino-Wittmann and Dall'Agnol, 2001), the increase in the number of chromosome sets in the evolution of a species can result in greater variability and higher heterozygosity, vigor, and adaptability (SchifinoWittmann, 2004). Strawberry is an octoploid and has undergone several levels of ploidization throughout its evolutionary history and may present a high variability in hybrids obtained from crosses (Hancock et al., 2008). In addition, the cultivars used in crosses show multivariate genetic divergence (Morales et al., 2011) and hence genetic variability among the hybrids is expected.

Table 1. Result of analysis of variance, means, coefficients of variation and standard deviation of the hybrids and controls for the characteristics number of commercial fruits per plant (NCF), average mass of commercial fruits (AMCF), mass of commercial fruit (MCF), mass of non-commercial fruits (MNCF), total mass of fruits (TMF), $\mathrm{pH}$, soluble solids (SS), titratable acidity (TA), soluble solids to titratable acidity ratio (Ratio), reducing sugars (RS), phenolic compounds (PC), pectin (PEC), ascorbic acid (AA), and anthocyanins (ANT). Guarapuava-PR, UNICENTRO, 2014.

\begin{tabular}{|c|c|c|c|c|c|c|c|c|c|c|c|c|c|c|c|}
\hline \multirow{2}{*}{ Sources of variation } & \multirow[b]{2}{*}{ DL } & \multicolumn{14}{|c|}{ Mean squares } \\
\hline & & NCF & AMCF & MFC & MNCF & TMF & $\mathrm{pH}$ & SS & TA & Ratio & $\mathbf{A R}$ & PC & $\begin{array}{l}\text { PEC } \\
\end{array}$ & $\mathbf{A A}$ & ANT \\
\hline Blocks & 9 & 3676.13 & 45.05 & 1091461.9 & 7060.05 & 1147404.2 & 0.0294 & 2.5527 & 0.1466 & 53.09 & 1.1535 & 1824.2 & 1.4573 & 113.14 & 99.38 \\
\hline Treatments (adjusted) & 193 & $1543.95^{* *}$ & $15.26^{\text {ns }}$ & 388896.34 & 2543.74 & $397852.31^{* \prime}$ & $0.0199^{\mathrm{ns}}$ & $0.6863^{\text {ns }}$ & $0.0221^{\mathrm{ns}}$ & $6.49^{\circ}$ & $0.1968^{\text {ns }}$ & $859.60^{\mathrm{ns}}$ & $0.8728^{*}$ & $144.30^{* *}$ & $135.26^{\prime \prime}$ \\
\hline Residue & 9 & 125.87 & 8.74 & 65579.32 & 17.71 & 66803.27 & 0.0136 & 0.5104 & 0.0085 & 2.00 & 0.1347 & 361.76 & 0.2105 & 26.33 & 12.80 \\
\hline \multicolumn{16}{|c|}{ Averages } \\
\hline Overall average & & 45.91 & 13.59 & 679.02 & 66.67 & 745.68 & 3.39 & 7.57 & 0.77 & 10.31 & 2.99 & 185.31 & 2.06 & 71.57 & 39.65 \\
\hline Average of controls ${ }^{1}$ & & 54.4 & 17.61 & 974.6 & 12.76 & 987.36 & 3.40 & 7.81 & 0.73 & 11.06 & 2.95 & 194.01 & 2.05 & 75.93 & 41.05 \\
\hline Average of hybrids & & 45.03 & 13.17 & 648.54 & 72.22 & 720.77 & 3.39 & 7.55 & 0.78 & 10.23 & 3.00 & 184.42 & 2.06 & 71.12 & 39.51 \\
\hline Weighted average $-\mu \mathrm{F}$ (Federer) & & 43.64 & 13.01 & 615.34 & 71.66 & 686.1 & 3.39 & 7.50 & 0.78 & 10.15 & 2.92 & 185.48 & 2.07 & 70.36 & 39.36 \\
\hline $\mathrm{CV}(\%)$ in controls and hybrids & & 24.44 & 21.76 & 37.71 & 6.31 & 34.66 & 3.43 & 9.44 & 11.90 & 13.74 & 12.24 & 10.26 & 22.29 & 7.17 & 9.02 \\
\hline $\mathrm{CV}(\%)$ in controls & & 20.62 & 16.78 & 26.27 & 32.98 & 26.18 & 3.42 & 9.14 & 12.60 & 12.80 & 12.45 & 9.80 & 22.36 & 6.76 & 8.71 \\
\hline $\mathrm{CV}(\%)$ in hybrids & & 24.91 & 22.44 & 39.49 & 5.83 & 35.86 & 3.43 & 9.47 & 11.83 & 13.84 & 12.21 & 10.31 & 22.28 & 7.22 & 9.05 \\
\hline $\mathrm{SD} \pm$ in controls & & 5.02 & 1.32 & 114.52 & 1.88 & 115.59 & 0.05 & 0.32 & 0.04 & 0.63 & 0.16 & 8.51 & 0.21 & 2.29 & 1.60 \\
\hline $\mathrm{SD} \pm$ in hybrids & & 15.87 & 4.18 & 362.16 & 5.95 & 365.52 & 0.16 & 1.01 & 0.13 & 2.00 & 0.52 & 26.89 & 0.65 & 7.26 & 5.06 \\
\hline $\mathrm{SD} \pm$ hybrids in different blocks & & 19.43 & 5.12 & 443.55 & 7.29 & 447.67 & 0.20 & 1.24 & 0.16 & 2.45 & 0.64 & 32.94 & 0.79 & 8.89 & 6.19 \\
\hline $\mathrm{SD} \pm$ in controls and hybrids & & 14.41 & 3.8 & 328.95 & 5.41 & 332 & 0.15 & 0.92 & 0.12 & 1.82 & 0.47 & 24.43 & 0.59 & 6.59 & 4.59 \\
\hline
\end{tabular}

DF: degrees of freedom. CV: coefficient of variation. SD: standard deviation. *Significant at 5\% probability. **Significant at $1 \%$ probability. ${ }^{\text {ns }}$ not significant by the $\mathrm{F}$ test.

Hybrids from the crosses 'Camarosa' $x$ 'Sweet Charlie' and 'Camarosa' $x$ 'Aromas' stood out for their production characteristics, with an estimated amplitude of 50.4 to 195.4 fruits for NCF, 13.2 to $20.4 \mathrm{~g}$ for AMCF, and 650.2 to $3056.25 \mathrm{~g}$ for MCF (Table 2). In both crosses, 92.3 and $68.7 \%$, respectively, of the hybrids surpassed the controls for the characteristics NCF and AMCF. These characteristics contributed to the good performance obtained for MCF and TMF in those crosses (Table 2). Hancock et al. (2008) found high correlations for productivity in the combination of characteristics, such as number and size of fruits, plant vigor, resistance to diseases, and adaptation to growing conditions. The cultivar Camarosa was a female genitor in these two crosses. The performance of hybrids obtained from crosses in which the cultivar Camarosa was one of the genitors may be due this cultivar being very vigorous and having high productivity, being able to reach an average productivity of 2,380 g/plant and $24.6 \mathrm{~g} / \mathrm{fruit}$ (Voth et al., 1994).

The crosses 'Festival Florida' x 'Aromas', 'Sweet Charlie' x 'Aromas', and 'Dover' x 'Aromas', i.e. crosses in which 'Aromas' was the male genitor also gave hybrids with a superior performance when compared to the controls for the characteristics NCF, MCF, and TMF (Table 2). Nevertheless, they did not surpass the performance of the crosses 'Camarosa' $x$ 'Sweet Charlie' and 'Camarosa' $\mathrm{x}$ 'Aromas', in which the cultivar Camarosa was the female genitor. 
Table 2. Percentage of strawberry hybrids with a positive effect in relation to the cultivars Camarosa and Camino Real in each of the crosses for the characteristics commercial fruits per plant (NCF), mass of commercial fruit (MCF), and total mass of fruits (TMF). Guarapuava-PR, UNICENTRO, 2014.

\begin{tabular}{|c|c|c|c|c|c|c|c|c|c|c|c|c|}
\hline \multirow[b]{2}{*}{ Cross } & \multicolumn{4}{|c|}{ _ $\ldots \ldots \ldots$} & \multicolumn{4}{|c|}{ 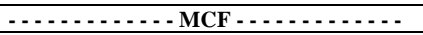 } & \multicolumn{4}{|c|}{ 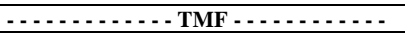 } \\
\hline & Average ${ }^{*}$ & Amplitude $^{* *}$ & $\begin{array}{l}\% \\
\text { híb }^{1}\end{array}$ & $\begin{array}{l}\% \\
\text { híb }^{2}\end{array}$ & Average & Amplitude & $\begin{array}{l}\% \\
\text { híb }^{1}\end{array}$ & $\begin{array}{l}\% \\
\text { híb }^{2}\end{array}$ & Average & Amplitude & $\begin{array}{l}\% \\
\text { híb }^{1}\end{array}$ & $\begin{array}{l}\% \\
\text { híb }^{2}\end{array}$ \\
\hline FS & 79.5 & $62.4-122.4$ & 26.9 & 26.9 & 1033.9 & $718.1-1782.6$ & 7.7 & 23.1 & 1128.4 & $791.3-1942.8$ & 15.4 & 23.1 \\
\hline $\mathrm{OM}$ & 84.9 & $47.4-117.4$ & 21.4 & 28.6 & 1246.8 & $670.9-2577.3$ & 14.3 & 28.6 & 1158.3 & $690.2-2664.8$ & 21.4 & 32.1 \\
\hline DS & 69.4 & $47.4-97.4$ & 14.8 & 18.5 & 900.16 & $743.4-989.7$ & 3.7 & 11.1 & 970.1 & $791.2-1088.2$ & 7.4 & 11.1 \\
\hline FA & 101.4 & $61.4-121.4$ & 38.5 & 38.5 & 1507.4 & $801.8-2045.2$ & 30.8 & 46.2 & 1578.0 & $826.9-2156.1$ & 30.8 & 46.2 \\
\hline SA & 70.9 & $45.4-115.4$ & 38.8 & 50.0 & 1002.8 & $640.5-1601.2$ & 16.7 & 44.4 & 1052.3 & $714.8-1693.1$ & 27.8 & 50.0 \\
\hline DA & 102.5 & $45.4-195.4$ & 36.5 & 43.7 & 2157 & $1477.8-3315.9$ & 37.5 & 37.5 & 2238.8 & $1499.6-3385.0$ & 37.5 & 37.5 \\
\hline $\mathrm{CS}$ & 108.7 & $55.4-195.4$ & 92.3 & 92.3 & 1555.6 & $836.9-3056.2$ & 76.9 & 92.3 & 1783.0 & $994.4-3100.3$ & 92.3 & 92.3 \\
\hline MA & 103.4 & $48.4-158.4$ & 13.6 & 18.2 & 1227.1 & $642.6-2416.5$ & 18.2 & 31.8 & 1514.4 & $733.2-2482.1$ & 18.2 & 22.7 \\
\hline MS & 68.4 & $46.4-86.4$ & 33.3 & 33.3 & 886.54 & $651.3-1061.7$ & 26.7 & 33.3 & 950.3 & $702.3-1193.5$ & 26.7 & 40.0 \\
\hline $\mathrm{CA}$ & 84.0 & $50.4-160.4$ & 68.7 & 68.7 & 1341.9 & $650.2-2646.1$ & 56.3 & 81.3 & 1356.6 & $691.1-2669.9$ & 62.5 & 81.3 \\
\hline
\end{tabular}

${ }^{*}$ Averages adjusted for the Federer Augmented Blocks model; ${ }^{* *}$ Range of data on the adjusted means of the hybrids for each cross; ${ }^{1} \%$ hib: Percentage of hybrids with positive effects superior to cultivar Camarosa; and ${ }^{2} \%$ hib: Percentage of hybrids with positive effects superior to cultivar Camino Real. FS: 'Festival Florida' x 'Sweet Charlie'; OM: 'Oso Grande' x 'Milsei Tudla'; DS: 'Dover' x 'Sweet Charlie'; FA: 'Festival Flórida' x 'Aromas'; SA: 'Sweet Charlie' x 'Aromas'; DA: 'Dover' x 'Aromas'; CS: 'Camarosa' x 'Sweet Charlie'; MA: 'Milsei Tudla' x 'Aromas'; MS: 'Milsei Tudla' x 'Sweet Charlie'; and CA: 'Camarosa' x 'Aromas'.

The cultivars Camarosa and Aromas, in addition to presenting excellent production characteristics described in their breeding programs (Voth et al., 1994; Shaw, 1998), are also adapted to the different climatic conditions in Brazil (Costa et al., 2015). Galvão et al. (2017) assessed seedlings originated from the same crosses, but constituted of different populations, and found a greater number of superior hybrids when compared to the mean in crosses in which the cultivars Camarosa and Aromas participated. Masny et al. (2016), in a study on genetic parameters, obtained positive values for the general combining ability (GCA) relative to commercial production characteristics in only three cultivars, among them Camarosa and Aromas. Vieira et al. (2017) assessed GCA and the specific combining ability (SCA) and found positive estimates for the cultivars Aromas and Camarosa for production characteristics. Therefore, these cultivars tend to contribute to increases in fruit production in crosses in which they are present since they present a higher proportion of favorable alleles for these characteristics.

In relation to the physicochemical characteristics, for the variable Ratio, the crosses 'Sweet Charlie' x 'Aromas', 'Festival Florida' x 'Aromas', 'Camarosa' x 'Sweet Charlie', 'Milsei Tudla' x 'Sweet Charlie', and 'Camarosa' x 'Aromas' presented from 33.33 to $87.5 \%$ of their hybrids with superior values when compared to the controls (Table 3). This is a very important characteristic because it is associated with flavor, which is related to the contents of sugars and acids, which, when at high and balanced values, give the fruits an excellent flavor (Kader, 1991; Hummer and Hancock, 2009). However, different cultivars may show significant differences between contents of chemical compounds (Cordenunsi et al., 2002; Hummer and Hancock, 2009). Agüero et al. (2015) found that genotype, environment and genotype $\mathrm{x}$ environment interaction determine the quality characteristics of strawberry fruits. For these authors, the air temperature, the date of harvest, the ratio between number of fruits harvested/number of leaves per plant and the occurrence of rainfall in the days prior to harvest influence production characteristics such as soluble solids content and fruit acidity.

Regarding the characteristic PEC, the crosses 'Dover' $x$ 'Sweet Charlie', 'Sweet Charlie' x 'Aromas', 'Milsei Tudla' x 'Aromas', and 'Camarosa' x 'Aromas' stood out with 77 to $100 \%$ of their hybrids with superior values compared to those found for the controls. The 
amplitude of pectin values among hybrids of these crosses was 2.06 to $5.08 \mathrm{~g}$ total pectin $/ 100 \mathrm{~g}$ pulp (Table 3). Regarding the contents of AA, except for the cross 'Sweet Charlie' x 'Aromas', the other crosses were superior from 30 to $77 \%$ when compared to the controls. For the content of ANT, from 30 to $95 \%$ of the hybrids were superior to the controls, the crosses 'Milsei Tudla' x 'Aromas', 'Camarosa' x 'Aromas', and 'Festival Florida' x 'Aromas' standing out (Table 3).

Table 3. Percentage of strawberry hybrids with positive effect in relation to the cultivars Camarosa and Camino Real in each of the crosses for the characteristics soluble solids to titratable acidity ratio (Ratio), pectin (PEC), ascorbic acid (AA), and anthocyanins (ANT). Guarapuava-PR, UNICENTRO, 2014.

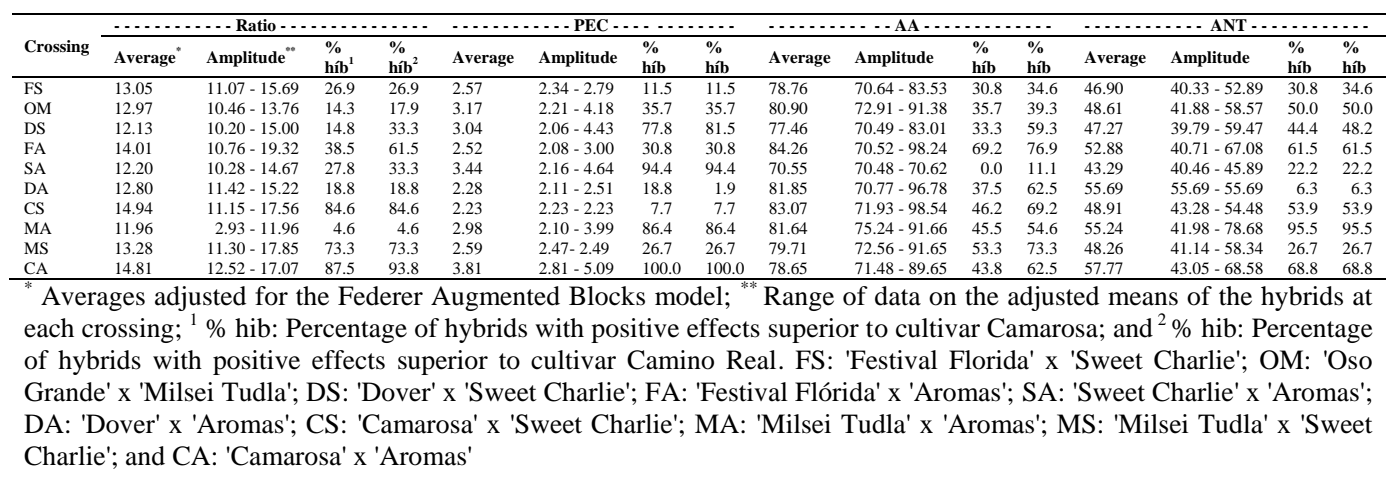

The cultivars Camarosa and Aromas, in crosses in which they participated as female and male genitors, respectively, produced superior hybrids when compared to the controls for production and physicochemical characteristics, contributing with more than $30 \%$ of their hybrids with results superior to the controls. However, the cultivars Milsei Tudla, Dover, and Sweet Charlie also presented contributions of superior hybrids compared to those found for the controls for the physicochemical characteristics in crosses in which they participated. Milsei Tudla and Sweet Charlie are cultivars characterized by producing fruits with an intense coloring and excellent flavor, presenting high contents of soluble solids and low acidity (Coelho Jr, 2016). As in our study Camargo et. al (2018) found that the hybrids that stood out for the chemical characteristics of the fruits, has as one of the parents the cultivars Festival, Sweet Charlie, Camarosa and Aromas.

The currently available cultivars are the result of selection mainly for production characteristics, combining alleles highly favorable for these characteristics. This was evidenced by Shaw and Larson (2008), who showed an increase of 1 to 3\% per year in production characteristics in a study comparing the performance of cultivars launched by United States breeding programs from 1945 to 1966 and 1993 to 2004. In addition, Hancock (1990) had already observed that fruit size has a polygenic inheritance with high heritability. Thus, genes favorable to productivity and size of fruits are present in crosses of our experiment

The consumer market is increasingly interested in foods with good nutritional and flavor characteristics. Basu et al. (2014) and Forbes-Hernandez et al. (2015) observed evidence that link strawberry consumption to beneficial health effects, including antioxidative, antiinflammatory, antihypertensive, and anticancer activity. However, in addition to nutritional aspects, strawberry flavor, resulting from the balance between sweetness and acidity, is one of the most important quality attributes demanded by the consumer that influences purchasing (Resende et al., 2008). Because of this, in addition to productivity characteristics, breeding 
programs have been intensifying the search for cultivars that present better nutritional and physicochemical characteristics (Capocasa et al, 2008). In this sense, selection based on a few characteristics can result in hybrids that are little balanced in their attributes since correlations are not positive among all characteristics (Hancock et al., 2008). The use of methodologies that allow the simultaneous assessment of characteristics may be a good strategy (Cruz et al., 2012).

Crosses among the current commercial cultivars have great potential to exploit variability as they have the advantage of already presenting favorable alleles. In our study, the crosses in which the female genitor Camarosa and the male genitor Aromas were present stood out, being the best for producing hybrids of prominence for production characteristics and the second best for quality.

The hybrids RVOM 22 ('Oso Grande' x 'Milsei Tudla'), RVDA 04 ('Dover' $\mathrm{x}$ 'Aromas'), RVCS 10 ('Camarosa' x 'Sweet Charlie'), RVCS 04 ('Camarosa' x 'Sweet Charlie'), and RVCA 06 ('Camarosa' $\mathrm{x}$ 'Aromas') stood out for the production characteristics NCF, MCF, and TMF. For the physicochemical characteristics Ratio, PEC, and ANT, the hybrids RVCS 10 ('Camarosa' x 'Sweet Charlie'), RVCA 15 ('Camarosa' x 'Aromas'), and RVMA 05 ('Milsei Tudla' $x$ 'Aromas') stood out (Table 4). The hybrids identified in this experiment are promising to advance in selection.

Table 4. Strawberry hybrids selected and superior to the best performance control (Camino Real) for the characteristics commercial fruits per plant $(\mathrm{NCF})$, mass of commercial fruit (MCF), total mass of fruits (TMF), soluble solids to titratable acidity ratio (Ratio), pectin (PEC), and anthocyanins (ANT). Guarapuava-PR, UNICENTRO, 2014.

\begin{tabular}{|c|c|c|c|c|c|c|c|}
\hline Crossing & Hybrids & $\mathrm{NCF}^{*}$ & MCF & TMF & Ratio & PEC & ANT \\
\hline Oso Grande x Milsei Tudla & RVOM 22 & 197.4 & 2577.3 & 2664.8 & & & \\
\hline Dover x Aromas & RVDA 04 & 195.4 & 3315.9 & 3385.0 & & & \\
\hline Camarosa x Sweet Charlie & RVCS 10 & 195.4 & 3056.2 & 3100.3 & 23.9 & & \\
\hline Camarosa x Sweet Charlie & RVCS 04 & 185.4 & 2836.7 & 2930.7 & & & \\
\hline Camarosa x Aromas & RVCA 06 & 160.4 & 2646.1 & 2669.8 & & & 68.6 \\
\hline Dover $\mathrm{x}$ Aromas & RVDA 18 & $60.0^{* *}$ & 2932.5 & 2989.1 & & & \\
\hline Dover x Aromas & RVDA 11 & 145.4 & & & & & \\
\hline Camarosa x Sweet Charlie & RVCS 09 & 145.4 & & & & & \\
\hline Camarosa x Sweet Charlie & RVCS 01 & 135.4 & & & & & \\
\hline Camarosa x Sweet Charlie & RVCS 07 & 135.4 & & & & & \\
\hline Camarosa x Aromas & RVCA 16 & 130.4 & & & & & \\
\hline Camarosa x Sweet Charlie & RVCS 11 & 125.4 & & & & & \\
\hline Festival Flórida x $S$. Charlie & RVFS 07 & 122.4 & & & & & \\
\hline Festival Flórida x Aromas & RVFA 14 & & & & 19.3 & & \\
\hline Camarosa x Aromas & RVCA 11 & & & & 19.2 & & \\
\hline Camarosa $\mathrm{x}$ Aromas & RVCA 15 & & & & & 5.1 & \\
\hline Camarosa x Aromas & RVCA 14 & & & & & 4.8 & \\
\hline Sweet Charlie x Aromas & RVSA 08 & & & & & 4.6 & \\
\hline Camarosa x Aromas & RVCA 13 & & & & & 4.6 & 66.7 \\
\hline Milsei Tudla x Aromas & RVMA 05 & & & & & & 78.7 \\
\hline Milsei Tudla x Aromas & RVMA 16 & & & & & & 77.2 \\
\hline Milsei Tudla x Aromas & RVMA 09 & & & & & & 70.6 \\
\hline Milsei Tudla x Aromas & RVMA 06 & & & & & & 69.6 \\
\hline Milsei Tudla x Aromas & RVMA 04 & & & & & & 68.7 \\
\hline Milsei Tudla x Aromas & RVMA 21 & & & & & & 68.7 \\
\hline Camarosa x Aromas & RVCA 02 & & & & & & 67.4 \\
\hline Festival Flórida x Aromas & RVFA 02 & & & & & & 67.1 \\
\hline Milsei Tudla x Aromas & RVMA 11 & & & & & & 64.6 \\
\hline Milsei Tudla x Aromas & RVMA 10 & & & & & & 62.6 \\
\hline Milsei Tudla x Aromas & RVMA 20 & & & & & & 61.7 \\
\hline
\end{tabular}




\section{REFERENCES}

Agüero JJ, Salazar SM, Kirschbaum DS and Jerez EF (2015). Factors affecting fruit quality in strawberries grown in a subtropical environment. Int. J. of Fruit Sci. 15: 223-234. doi: 10.1080/15538362.2015.1017427

Antunes LEC and Peres NA (2013). Strawberry production in Brazil and South America. Int. J. Fruit Sci. 13: 1-2. doi: $10.1080 / 15538362.2012 .698147$

Antunes LEC, Ristow NC, Krolow ACR, Carpenedo S et al. (2010). Yield and quality of strawberry cultivars. Hortic. Bras. 28: 222-226.

Basu A, Nguyen A, Betts NM and Lyons TJ (2014). Strawberry as a functional food: an evidence-based review. Crit. Rev. Food. Sci. Nutr. 54: 790-806. doi: 10.1080/10408398.2011.608174

Camargo LKP, Resende JTV, Camargo CK, Kurchaidt SM, et al. (2018). Post-harvest characterization of strawberry hybrids obtained from the crossing between commercial cultivars. Rev. Bras. Frutic. 40: 1-4. doi: 10.1590/010029452018821

Capocasa F, Diamantia J, Tulipanib S, Battino M, et al. (2008). Breeding strawberry (Fragaria X ananassa Duch) to increase fruit nutritional quality. Biofactors. v. 34, n. 1, p. 67-72.

Coelho Jr JM (2016). Strawberry cultivars: Knowing to expand and reduce the environmental impacts. Rev. Geama. 5: 138-147.

Cordenunsi BR, Nascimento JRO, Genovese MI and Lajolo FM (2002). Influence of cultivar on quality parameters and chemical composition of strawberry fruits grown in Brazil. J. Agric. Food Chem. 50: 2581-2586. doi: 10.1021/jf011421i

Costa AF, Leal NR, Ventura JA, Simões L, et al. (2015). Adaptability and stability of strawberry cultivars using a mixed model. Acta Sci. Agron. 37: 435-440. doi: 10.4025/actasciagron.v37i4.18251

Cruz CD (2013). Genes: a software package for analysis in experimental statistics and quantitative genetics. Acta Sci. Agron. 35: 271-276. doi: 10.4025/actasciagron.v35i3.21251

Cruz CD, Regazzi AJ and Carneiro PCS (2012). Modelos Biométricos aplicados ao melhoramento genético, 4th, UFV, Viçosa-MG.

Fagherazzi AF, Grimaldi F, Kretzschmar AA, Molina AR, et al. (2017). Strawberry production progress in Brazil. In: VIII International Strawberry Symposium 1156. 2016. p. 937-940.

FOOD AND AGRICULTURE ORGANIZATION OF THE UNITED NATIONS. Production/crops/strawberries. Available at http://www.fao.org/faostat. Accessed on: July 23, 2018

Federer W (1956). Augmented (or hoonuiaku) designs. Hawaiian Planters' Record. 55: 191-208.

Forbes-Hernandez TY, Gasparrini M, Afrin S, Bompadre S, et al. (2015). The healthy effects of strawberry polyphenols: which strategy behind antioxidant capacity? Critical Crit. Rev. Food. Sci. Nutr. 56: 46-59. doi: $10.1080 / 10408398.2015 .1051919$

Galvão AG, Resende LV, Maluf WR, Resende JTV, et al. (2017). Breeding new improved clones for strawberry production in Brazil. Acta Sci. Agron. 39: 149-155. doi: 10.4025/actasciagron.v39i2.30773

Gomes GP, Gonçalves LS, Sekiya A, Euzebio MP, et al. (2016). Registro e proteção de olerícolas no Brasil, período de 1998 a 2014. Hortic. Bras. 34: 19-26. doi: 10.1590/S0102-053620160000100003

Hancock JF (1990). Ecological genetics of natural strawberries species. HortScience. 25: 869-871.

Hancock JF, Sjulin TM and Lobos GA (2008). Strawberries. In: Hancock JF (ed). Temperate Fruit Crop Breeding. Springer, Michigan, USA, pp 393-437.

Hummer KE and Hancock J (2009). Strawberry genomics: botanical history, cultivation, traditional breeding, and new technologies. In: Folta KM and Gardiner SE (eds). Genetics and genomics of Rosaceae, Plant Gene. Springer, Gainsville: Flórida, USA, pp 413-435

Kader AA (1991). Quality and its maintenance in relation to the postharvest physiology of strawberry. In: Dale A and Luby JJ (eds). The strawberry into the 21 st. Timber Press, Portland: Oregon, USA, pp 145-152

Masny A, Pruski K, Żurawicz E and Mądry W (2016). Breeding value of selected dessert strawberry (Fragaria× ananassa Duch.) cultivars for ripening time, fruit yield and quality. Euphytica. 207: 225-243. doi: 10.1007/s10681-015-14806

Morales RGF, Resende JTV, Faria MV, Andrade MC, et al. (2011). Genetic similarity among strawberry cultivars assessed by RAPD and ISSR markers. Scientia Agricola. v.68. n.6. p.665-670. Doi: 10.1590/S010390162011000600010

Murashige T and Skoog F (1962). A revised medium for rapid growth and bioassays with tobacco tissue cultures. Physiol. Plantarum. 15: 473-497.

Oliveira ACB and Antunes LEC (2016). Melhoramento genético e principais cultivares. In: Antunes LEC, Reisser Jr C and Schwengbe JE (eds). Morangueiro, 1st. EMBRAPA, Brasília, DF. pp 139-145

Resende JTV de, Camargo LK, Argandoña EJ, Marchese A, et al. (2008). Sensory analysis and chemical characterization of strawberry fruits. Hortic. Bras. 26: 371-374. doi: 10.1590/S0102-05362008000300015

Schifino-Wittmann MT (2004). Poliploidia e seu impacto na origem e evolução das plantas silvestres e cultivadas. Rev. Bras. Agrocienc. 10: 151-157. 
Schifino-Wittmann MT and Dall'Agnol M (2001). Gametas não reduzidos no melhoramento de plantas. Ciênc. Rural. 31: 169-175. doi: 10.1590/S0103-84782001000100028

Shaw DV (1998). Strawberry plant named 'Aromas'. U.S. Patente 10,451. U.S. Oakland: University of Califórnia,

Shaw DV and Larson KD (2008). Performance of early-generation and modern strawberry cultivars from the University of California breeding programme in growing systems simulating traditional and modern horticulture. J. Hortic. Sci. Biotechnol. 83: 648-652. doi: 10.1080/14620316.2008.11512437

Vieira S, Souza D, Martins I, Ribeiro G, et al. (2017). Selection of experimental strawberry (Fragaria x ananassa) hybrids based on selection indices. Genet. Mol. Res. 16: 1-11. doi: 10.4238/gmr16019052

Voth V, Shaw DV and Bringhurst RS (1994). Strawberry plant called 'Camarosa'. U.S. Patent 8,708. U.S. Patent and Trademark Office, Wash., D.C.

Wrege MS, Steinmetz S, Reisser Junior C and Almeida IR (2011). Atlas climático da Região Sul do Brasil: Estados do Paraná, Santa Catarina e Rio Grande do Sul. 1st. Pelotas: Embrapa Clima Temperado, Colombo: Embrapa Florestas. 336p. 